\title{
CONSTRUCTION PROJECT MANAGEMENT IN A DEVELOPING ECONOMY: CONSULTANTS PERCEPTION OF CHALLENGES AND SOLUTIONS IN NIGERIA
}

\author{
Chris Chukwuji ${ }^{1}$, Hyginus Opara ${ }^{2}$, Reuben Okereke ${ }^{3}$
}

\author{
${ }^{1}$ Department of Building, \\ Imo State University \\ Owerri, Nigeria \\ ${ }^{2}$ Department of Civil \\ Engineering, Imo State \\ University Owerri, \\ Nigeria \\ ${ }^{3}$ Department of Quantity \\ surveying, Imo State \\ University Owerri, \\ Nigeria
}

Received: 20 April 2020 Revised: 7 May 2020 Accepted: 27 July 2020

\begin{abstract}
Construction projects are usually of two types, the infrastructure and real estate projects. Both types of projects are very essential for the development of any nation. PM consultants provides procurement services from conception to completion of any projects. In this paper, a random survey of PMCs perspectives on challenges often encountered during the construction of mega projects in a developing economy, were conducted. The PMCs' opinions were analyzed with statistical tools of mean and relevance important index RII to evaluate their claims. Results shows that the challenges were real and enormous; the prescribed solutions can eliminate the challenges and the suggested benefits of PM services were justified by the results. The study concluded that PMCs are nation's development partners and by using their services, public projects can be realized successfully. It recommended that PMCs in every project, must ensure proper conception, scope definition, and efficient management of stakeholders and local needs regarding such project.
\end{abstract}

Keywords: Construction project management, challenges, developing economy, project management consultants, solutions.

\section{INTRODUCTION}

In mega construction projects, consultant management services is very necessary. Small scale projects, requires no high level management, but large projects need such level of project management services. According to Anurag and Snehal (2016) mega project execution involve multiple and complex activities which must be supervised by senior managers. Project management consultants provide in their team, design engineers, construction engineers, quantity surveyors, project architects and construction managers. The use of project management consultants is acceptable in most countries as a means of achieving better management of projects. PM consultants ensures that construction projects are properly executed within agreed time and budget (Nikumbh, \& Pimplikar, 2014). The benefits of infrastructure projects in the economic growth of developing counties is quite understandable (Srinivasu, \& Rao, 2013). Management consultants handle projects based on their integrity and longtime experiences. When any completed infrastructure project fails to meet public desire it becomes an economic loss to the country (Liu, 2009). According to Nyariranwge and Oluwayomi (2016) construction sector contributes about $5 \%$ to economic profile of South Africa. Since the year 2000, SA has continued to enforce her infrastructure policy which resulted in the completion of projects such as Gautrain Rapid Rail system, the Gauteng Freeway Improvement program and the Bus Rapid Transit (Nyariranwge, \& Oluwayomi, 2016). South Africa government targeted to use infrastructure projects to generate a minimum of two million jobs, reduce unemployment and stimulate economic growth by the year 2020 (EDD, SA, 2011). Successful delivery of mega

Corresponding author. Email: chris.chukwuji@gmail.com

ISSN 2560-4961 (online)

Copyright (C) 2020, The Authors. Published by IPMA Serbia.

This is an open access article under the CC BY-NC 4.0 license (https://creativecommons.org/licenses/by$\mathrm{nc} / 4.0 /)$

doi: $10.18485 /$ epmj.2020.10.1.3 
infrastructure projects will justify the huge investment of public funds on them hence, they are given attention as other critical social services (EDD, SA, 2011). Most project managers often remember they have worrisome records of challenges when commissioned to manage projects in developing countries; these challenges probably are caused by inherent political instability, excessively bureaucracy, wrong contract award procedures, and lack of adequate public infrastructure (Faniran, 1999). Such peculiar challenges in developing countries requires special consideration by PM consultants for them to deliver any public infrastructure projects successfully (Faniran, 1999).

\section{IMPORTANCE OF INFRASTRUCTURES IN NATIONAL DEVELOPMENT}

Infrastructure is the driving force of industrialization, and a vehicle for development of any country (Sharma, \& Vashist, 2010). According to Sarkar (2009) adequate and functional infrastructure enhances the industrial productivity of a country. The provision of extensive and functioning infrastructure reduces income inequalities and poverty in several nations (World Economic Forum, 2010). The report of many studies on the relationship between level of infrastructure and gross domestic product (GDP) suggests a positive correlation between the two. Servén (2010) in his research, proposed that $1 \%$ increase in the physical infrastructure of a country may lead to about $2 \%$ growth in GDP. Calderón, Moral-Benito and Servén (2009) in their report cited World Bank observation that a $10 \%$ rise in infrastructure assets directly increases GDP by up to a percentage point. In another World Bank (2006) report, poor infrastructure was depicted as a potentials impediment to a nation's economic growth and international competitiveness. Willoughby (2004) once agreed that insufficient infrastructure can lead to loss of quality life, illness and many death in a country. Esfahani and Ramírez (2003) argued that the longtime contribution of infrastructure to the economy of a nation is always greater than the initial expenditure on them. Regular reports on the quantum contribution of infrastructure projects to economic growth have spurred many national governments to give it high priority on their agendas (Olayiwola, \& Adeleye, 2005). Developing counties must invest in efficient infrastructure to achieve higher productivity (Akinyosoye, 2010).

\section{PROJECT MANAGEMENT CONSULTANCY SERVICES}

Project management services is absolute necessary in mega construction projects to ensure faster and proper completion on a target time and budget. Most reputable and widely used management consultants rightly understood that their prime role in any project is to meet the commission deadlines given by the financiers. Knowledgeable clients' often employ the services of project management consultants knowing they will work to their requirements and satisfaction. There is no hard and fast rule on the method of project management services, it all depends on the type of services the client wants the consultants to provide (Dzulkarnaen, 2005). Project is a temporary endeavor with a specific beginning and end and creates a unique product, service or result (PMBOK, Fifth Edition) A review of previous studies shows that the duties of management consultants may include some of the roles mentioned below (Anurag, \& Snehal, 2016):

- carryout initial and effective planning of the entire project;

- ensure that projects and related activities are completed within; scheduled time, quality and budget.

- providing guidelines regularly to contractors;

- organize periodic meetings to reviews progress of work;

- $\quad$ assign duties to team members

- supervising all the project management teams;

- continuous planning, forecasting and rescheduling of various activities;

- monitoring different stages of construction;

- certifying the quality of each stage of work;

- advise on the type of subcontractors, and suppliers for the project. 


\section{RESEARCH METHOD}

A survey of consultants' opinions on project management services was conducted through closed structured questionnaire, administered to randomly selected construction professionals in Owerri, the capital city of Imo State, southeast of Nigeria. A total of fifty (50) questionnaires were distributed to them, out of which forty seven (47) representing 94\% were properly completed and returned. The opinion areas demanded in the survey are: challenges to project management services in the country and possible solution for effective project delivery in developing economy. Data collected from the survey were presented in Tables. 1 to 4 . The respondents' opinions were assessed on five point Likert scale and analysed with mean and relative importance index (RII). Decision rule on the RII values are as follows:

RII $<0.60,=$ low rating; $0.60 \leq \mathrm{RII}<0.80,=$ high rating; and $\mathrm{RII} \geq 0.80$, = very high rating

Table 1: Professionals respondents

\begin{tabular}{|c|l|c|c|c|}
\hline S/N & Professionals & $\begin{array}{c}\text { No. of Questionnaires } \\
\text { Distributed }\end{array}$ & $\begin{array}{c}\text { No. of Questionnaires } \\
\text { Returned }\end{array}$ & $\begin{array}{c}\text { (\%) of Total } \\
\text { Questionnaires Rtnd }\end{array}$ \\
\hline 1 & Architects & 10 & 10 & 21.28 \\
\hline 2 & Construction Engineers & 10 & 10 & 21.28 \\
\hline 3 & Quantity Surveyors & 10 & 10 & 21.28 \\
\hline 4 & Construction Managers & 10 & 10 & 21.28 \\
\hline 5 & Estate Surveyors & 10 & 7 & 14.89 \\
\hline & Total & $\mathbf{5 0}$ & $\mathbf{4 7}$ & $\mathbf{1 0 0}$ \\
\hline
\end{tabular}

Table 2: Project management challenges in developing countries

\begin{tabular}{|c|l|c|c|c|}
\hline $\mathbf{S} / \mathbf{N}$ & Challenge Factors & $\overline{M e a n}$ & RII & Rank \\
\hline 1 & Administrative issues; social, political, and economic & 4.15 & 0.83 & 2 nd \\
\hline 2 & Government as the only prime mover of projects & 4.15 & 0.83 & 2 nd \\
\hline 3 & Lack of qualified and experienced management technocrats & 3.95 & 0.79 & $3 \mathrm{rd}$ \\
\hline 4 & $\begin{array}{l}\text { Top management inadequate knowledge of project management } \\
\text { role in infrastructure delivery }\end{array}$ & 4.30 & 0.86 & $1 \mathrm{st}$ \\
\hline 5 & Scarce resources for project execution & 3.95 & 0.79 & $3 \mathrm{rd}$ \\
\hline 6 & Lack of necessary public infrastructure & 4.15 & 0.83 & $2 \mathrm{nd}$ \\
\hline 7 & Bribery and corruption among stakeholders & 4.30 & 0.86 & $1 \mathrm{1st}$ \\
\hline 8 & Cultural issues in project communities & 3.95 & 0.79 & $3 \mathrm{3rd}$ \\
\hline 9 & Project environment issues; social, political, and economic & 4.00 & 0.80 & $2 \mathrm{2nd}$ \\
\hline
\end{tabular}

Table 3: Project management solution factors in developing countries

\begin{tabular}{|c|l|c|c|c|}
\hline S/N & Solution Factors & Mean & RII & Rank \\
\hline 1 & $\begin{array}{l}\text { Plan and apply efficient and effective project management } \\
\text { strategies }\end{array}$ & 4.30 & 0.86 & $1 \mathrm{st}$ \\
\hline 2 & Locate and collaborate with project implementers/sponsors & 4.30 & 0.86 & $1 \mathrm{st}$ \\
\hline 3 & Identify local needs and conditions & 4.30 & 0.86 & $1 \mathrm{st}$ \\
\hline 4 & $\begin{array}{l}\text { Outline the benefits and costs effectiveness of using project } \\
\text { management services }\end{array}$ & 4.00 & 0.80 & $3 \mathrm{rd}$ \\
\hline 5 & Select the best project management team & 4.15 & 0.83 & $2 \mathrm{nd}$ \\
\hline 6 & Sell the project management concept to stakeholders & 4.02 & 0.80 & $3 \mathrm{rd}$ \\
\hline 7 & $\begin{array}{l}\text { Understand and use other project management support networks } \\
\text { available }\end{array}$ & 4.15 & 0.83 & $2 \mathrm{nd}$ \\
\hline 8 & Reduce job threats of insecurity, low income, poor careers, etc. & 4.02 & 0.80 & $3 \mathrm{rd}$ \\
\hline
\end{tabular}


Table 4: Benefits of construction project management services

\begin{tabular}{|c|l|c|c|c|}
\hline S/N & Benefits & $\overline{\mathbf{M}}$ & RII & Rank \\
\hline 1 & Protects the best interest of the client & 4.30 & 0.86 & $1 \mathrm{st}$ \\
\hline 2 & Reduces overall project cost & 4.30 & 0.86 & $1 \mathrm{st}$ \\
\hline 3 & Centralizes communication & 4.25 & 0.85 & $2 \mathrm{nd}$ \\
\hline 4 & Enhance effective management of project team & 4.20 & 0.84 & $3 \mathrm{rd}$ \\
\hline 5 & Enhance quality control and good workmanship & 4.20 & 0.84 & $3 \mathrm{rd}$ \\
\hline 6 & Provide realistic and reliable budget & 4.20 & 0.84 & $3 \mathrm{rd}$ \\
\hline 7 & Optimize design and construction schedule & 4.15 & 0.83 & 4 th \\
\hline 8 & Protect client from unnecessary liability & 4.15 & 0.83 & 4 th \\
\hline 9 & Provide proper management of resources & 4.20 & 0.84 & $3 \mathrm{rd}$ \\
\hline 10 & Provide effective and reliable documentation of project & 4.15 & 0.83 & 4 th \\
\hline
\end{tabular}

\section{DISCUSSIONS OF RESULTS}

\subsection{Project management challenges in developing countries}

Table 2. Shows that among the nine critically identified challenge factors, six have "very high" relevance importance index RII $\geq 0.80$; the remaining three factors have just "high" relevance of index $0.60 \leq \mathrm{RII}<0.80$ relevance. The challenge factors; top management inadequate knowledge of project management role in infrastructure delivery and, bribery and corruption among stakeholders tied to 1st rank with RII $=0.86$. Administrative issues; government as the only prime mover of projects, lack of necessary public infrastructure and project environment issues tied to the second position in order of importance with RII $=0.83$. Lack of qualified and experienced management technocrats, cultural issues in project communities, and scarce resources for project execution tied to the third position in order of importance with RII $=0.79$ These results agrees with the consultants perspective of project management challenges in the developing economy like Nigeria and other Sub-Saharan countries (Faniran, 1999).

\subsection{Project management solution factors in developing countries}

Table 3. Shows that the RII for all the eight proposed project management solution have relevance index of 0.80 and above, which implies "very high" level of relevance. The indices; plan and apply efficient and effective project management strategies, locate and collaborate with project implementers/sponsors and identify local needs and conditions tied to 1 st rank with RII $=0.86$. The indices; select the best project management team; understand and use other project management support networks available tied to the second position in order of importance with RII $=0.83$. Outline the benefits and costs effectiveness of using project management services and reduce job threats, tied to third position with RII $=0.80$. These results fully confirms the consultants' perspectives of the proposed project management solution for executing projects in developing economy.

\subsection{Benefits of construction project management services}

Table 4. Shows that the RII for all the ten suggested project management benefits have relevance index above 0.80 , which implies "very high" level of relevance. The following indices; protects the best interest of the client, and reduces overall project cost tied to $1 \mathrm{st}$ rank with RII $=0.86$. Centralizes communication took the $2^{\text {nd }}$ rank with 0.85 RII. Enhance effective management of project team, enhance quality control and good workmanship, provide realistic and reliable budget and provide proper management of resources tied to 3rd rank with RII $=0.84$. Optimize design 
and construction schedule, protect client from unnecessary liability and provide effective and reliable documentation of project tied to $4^{\text {th }}$ position with RII $=0.83$. These results also justified professional respondents' perspectives on the benefits of project management services in executing projects in developing economy.

\section{CONCLUSION}

Project management consultants are development partners and by using their services, public projects can be realized successfully. However PMCs face various challenges in developing countries, different from those in industrialized countries. It is noted that properly managed infrastructure and real estate projects stimulate economic growth of any nation. There are many identified challenging factors that militate against successful delivery of projects in developing countries and Project Managers' role is to tackle professionally, those challenging factors and ensure that projects are delivered ab niso.

\section{RECOMMENDATION}

Management consultants in every project, must ensure proper conception, definition of work scope, adequate financial and stakeholder management, use of best team members and identification of local needs and conditions. Such approach will effectively address the challenges frequently encountered in procuring public projects in developing economy.

\section{REFERENCES}

Akinyosoye, M. (2010). Infrastructure Development in Nigeria Road Map to Sustainable Development. Working Paper, Green Hill Technical Services Ltd., Lagos.

Anurag, S., \& Snehal, D. (2016). Role of Project Management Consultancy. Construction International Journal of Technical Research and Applications. eISSN: 2320-8163

Association for Project Management. (2006). APM Body of Knowledge. Association for Project Management, Buckinghamshire.
Calderón, C., Moral-Benito, E., \& Servén, L. (2009). Is Infrastructure Capital Productive. A Dynamic Heterogeneousch. World Bank Policy Research Working Paper Number 5682.

Dzulkarnaen, I. (2005). Services Provided by Project Management Consultant in Malaysian Construction Industry, MSc Thesis, Faculty of Civil Engineering, Universiti Teknologi Malaysia.

Economic Development Department, Republic of South Africa. (2011). The New Growth Path Framework.

Esfahani, H. S., \& Ramírez, M. T. (2003). Institutions, Infrastructure, and Economic Growth. Journal of Development Economics. $\quad 70, \quad$ pp. 443-477. http://dx.doi.org/10.1016/S03043878(02)00105-0

Faniran, O. O. (1999). The Role of Construction Project Planning in Improving Project Deliveryi In Developing Countries. Proceedings of the 2nd International Conference on Construction Industry Development, and 1st Conference of CIB TG 29 on Construction in Developing Countries.

Liu, L. (2009). How does strategic uncertainty and project sponsorship relate to project performance. Management Research News. 32(3), pp. 239 - 253.

Nikumbh, A. R., \& Pimplikar, S. S. (2014). Role of Project Management Consultancy in Construction Project IOSR. Journal of Mechanical and Civil Engineering (IOSRJMCE)

Nyariranwge, M., \& Oluwayomi, B. (2016). Impact of Project Manager's Leadership Competences on Complex Mega Infrastructure Project Performance: $A$ literature review emerging trends in construction organizational practices and project management knowledge area.

Olayiwola, L. M., \& Adeleye, O. A. (2005). Rural Infrastructural Development in Nigeria: Between 1960 and 1990; Problems and Challenges. Journal of Social Sciences. 11, pp. 91-96.

Presidential Infrastructure Coordinating Commission, Republic of South Africa. 
(2012). A Summary of the South African National Infrastructure Plan.

Project Management Institute. (2013). A Guide to Project Management Body of Knowledge, (PMBOK) Fifth Edition, Project Management Institute, Inc. Pennsylvania 19073-3299

Sahoo, P., Dash, R. K., \& Nataraj, G. (2010). Infrastructure Development and Economic Growth in China. IDE Discussion Paper No. 261, Institute of Developing Economies, JETRO.

Sarkar, S. (2009). Disparities in Infrastructure Development: An Inter-District Analysis of West Bengal State. The IUP Journal of Infrastructure. VII, pp. 56-78.

Servén, L. (2010). Infrastructure and Growth. http://go.worldbank.org/TQMEWOD650

Sharma, V. K., \& Vashist, R. L. (2010). An Evaluation of Infrastructure Development in the Hilly Areas. The IUP Journal of Infrastructure. 8, pp. 38-50.

Srinivasu, B., \& Rao, P. S. (2013). Infrastructure Development and Economic Growth: Prospects and Perspectives. Journal of Business Management and Social Science Research. 2(1), pp. 81-91.

The World Bank. (2006). Infrastructure at the Crossroads: The International Bank for Reconstruction and Development/The World Bank, Washington DC.

The World Bank. (2013). Infrastructure. Washington DC.

Willoughby, C. (2004). Infrastructure and the MDGs, sponsored by DFID

World Economic Forum. (2010). The Global Competitiveness Report 2010-2011. World Economic Forum, Geneva. 